This is the accepted version of the article Reis FS, Stojkovic D, Barros $L$, Glamočlija J, Cirić A, Soković M, Martins A, Vasconcelos MH, Morales $P$, Ferreira ICFR. Can Suillus granulatus (L.) Roussel be classified as a functional food? Food Funct. 2014;5(11):2861-9.

http://dx.doi.org/10.1039/c4fo00619d 


\section{Can Suillus granulatus (L.) Roussel be classified as a functional food?}

Filipa S. Reis ${ }^{\mathrm{a}, \mathrm{b}, \mathrm{c}}$, Dejan Stojkovićd ${ }^{\mathrm{d}}$, Lillian Barros ${ }^{\mathrm{a}}$, Jasmina Glamočlija ${ }^{\mathrm{d}}$, Ana Ćirićd, Marina Sokovićd, Anabela Martins ${ }^{\mathrm{a}}$, M. Helena Vasconcelos ${ }^{\mathrm{c}, \mathrm{e}}$, Patricia Morales ${ }^{\mathrm{b}}$, Isabel C.F.R. Ferreira ${ }^{a^{*}}$

${ }^{a}$ Mountain Research Center (CIMO), ESA, Polytechnic Institute of Bragança, Campus de Santa Apolónia, Ap. 1172, 5301-855 Bragança, Portugal.

${ }^{\mathrm{b}}$ Dpto. Nutrición y Bromatología II, Facultad de Farmacia, Universidad Complutense de Madrid (UCM), Pza Ramón y Cajal, s/n, E-28040 Madrid, Spain.

${ }^{\mathrm{c}}$ Cancer Drug Resistance Group, IPATIMUP - Institute of Molecular Pathology and Immunology of the University of Porto, Rua Dr. Roberto Frias s/n, 4200-465 Porto, Portugal.

${ }^{d}$ University of Belgrade, Department of Plant Physiology, Institute for Biological Research "Siniša Stanković”, Bulevar Despota Stefana 142, 11000 Belgrade, Serbia. ${ }^{e}$ Laboratory of Microbiology, Department of Biological Sciences, Faculty of Pharmacy of the University of Porto, Rua de Jorge Viterbo Ferreira $.^{\circ}{ }^{2} 28,4050-313$ Porto, Portugal.

* Corresponding author. Tel.: +351 273 303219; fax: +351 273325405.

E-mail address: iferreira@ipb.pt (I.C.F.R. Ferreira). 


\begin{abstract}
The present work outlines a detailed chemical characterization of Suillus granulatus species, besides the antioxidant and antimicrobial properties of their methanolic extracts. The study was carried out with samples drawn from Portugal and Serbia in order to prove that though mushrooms are strongly influenced by the environment in which they develop, they have a specific chemical profile that can be typical of their genus/species. The studied species proved to be healthy foods, low in fat and rich in protein and carbohydrates, with mannitol and trehalose being the main free sugars detected. They also proved to be a source of organic and phenolic acids, as well as mono- and polyunsaturated fatty acids and tocopherols. The Serbian samples revealed higher antioxidant and antimicrobial potential. Accordingly, we find that the $S$. granulatus species is likely to be considered a functional food, since it is a source of nutraceutical and biologically active compounds.
\end{abstract}

Keywords: Chemical characterization; nutraceuticals, bioactive compounds; antioxidant potential; antimicrobial activity. 


\section{Introduction}

Due to current daily habits, busy lifestyles and the consequent increase in several chronic diseases, there is a need to develop alternative food sources which while satisfying consumer demand, also have beneficial effects on health. Functional foods appear in this context. Because of the complexity of the term "functionality", no agreed and universally accepted definition for this group of food currently exists. ${ }^{1}$ Furthermore, functional foods have been considered as a concept rather than as a well-defined group of food products. The European Commission's Concerted Action on Functional Food Science in Europe (FUFOSE) stated that functional food is "a food that beneficially affects one or more target functions in the body beyond adequate nutritional effects in a way that is relevant to either an improved state of health and well-being and/or reduction of risk of disease. It is consumed as part of a normal food pattern. It is not a pill, a capsule or any form of dietary supplement". ${ }^{2}$ A functional food can be a natural food or a food to which a component has been added or removed by technological or biotechnological means. ${ }^{3}$ People used to associate the term "functional food" to technological or genetically-modified food. Indeed, the enrichment or addition of functional ingredients, as well as the removal of some compounds with negative effects induced by food technology procedures, or the alteration of food products to enhance their nutritional value using genetic modifications, constitute a category of functional foods. ${ }^{4}$ However, since the definition of functional foods is related with the beneficial effect that goes beyond those of traditional nutrients, if it is scientifically proven that certain compounds present in some food reduces for example, the risk of developing a certain illness, this food can be considered a functional food and this may include natural products. ${ }^{4}$ 
Suillus granulatus (L.) Roussel, known as the "weeping bolete", is an edible mushroom with a white, soon yellowish and non-staining flesh. It has a mild to slightly fragrant odour and tastes mild. ${ }^{5}$ Although this species (as all the Suillus species) is not one of the most consumed as a delicacy, such as truffles or morels, it is widely harvested and consumed by the general population, particularly those who traditionally practice mushroom picking. Because of its mild taste, it is often mixed with other species to improve taste / flavour attributes. ${ }^{6}$

Some reports involving this species can be found. Some are ecological studies which tried to prove that this ectomycorrhizal fungus could utilise litter as a source of nutrients and therefore reduce the negative effects of litter accumulation in forest ecosystems. ${ }^{7}$ Another study describs a $\beta$-carboline compound isolated from $S$. granulatus with a weak anti-HIV-1 activity. ${ }^{8}$ Concerning the chemical characterization of this species, there are few reports published regarding the fatty acid, ${ }^{9}$ organic acid phenolic compound compositions and antioxidant activity. ${ }^{10}$

The present work intends to take the first step towards classifying Suillus granulatus as a functional food, providing a detailed chemical analysis of the species which proves that this is a source of nutraceuticals and/or biologically active molecules. By comparing mushrooms collected from different locations it was intended to analyse the different chemical profiles, in order to confirm whether they remain unaltered depending on the surrounding environment.

\section{Experimental}

\section{Mushroom species}

Suillus granulatus (L.) Roussel wild samples were collected in Bragança (Northeast of Portugal) and in Lipovica Forest, near Belgrade (Serbia), in the autumn of 2012. The 
authentications were undertaken at the Polytechnic Institute of Bragança and Institute for Biological Research, Belgrade. Voucher specimens were deposited at the herbarium of the School of Agriculture of the Polytechnic Institute of Bragança, Portugal, and at the Fungal Collection Unit of the Mycological Laboratory, Department for Plant Physiology, Institute for Biological Research "Siniša Stanković", Belgrade, Serbia, respectively.

All samples were lyophilised (FreeZone 4.5 model 7750031, Labconco, Kansas City, MO, USA), reduced to a fine dried powder (20 mesh), mixed to obtain homogenous samples and stored in a desiccator, protected from light, until further analysis.

\section{Standards and Reagents}

Acetonitrile $99.9 \%, n$-hexane $95 \%$ and ethyl acetate $99.8 \%$ were of HPLC grade from Fisher Scientific (Lisbon, Portugal). The fatty acids methyl ester (FAME) reference standard mixture 37 (standard 47885-U) was purchased from Sigma (St. Louis, MO, USA), as well as other individual fatty acid isomers, sugar (D(-)-fructose, $\mathrm{D}(-)$ mannitol, $\mathrm{D}(+)$-raffinose pentahydrate, and $\mathrm{D}(+)$-trehalose $)$, tocopherol $(\alpha-, \beta-, \gamma-$, and $\delta$-isoforms) and organic acid (oxalic, quinic, malic, citric and fumaric acid) standards. Racemic tocol, $50 \mathrm{mg} / \mathrm{mL}$, was purchased from Matreya (Pleasant Gap, PA, USA). 2,2Diphenyl-1-picrylhydrazyl (DPPH) was obtained from Alfa Aesar (Ward Hill, MA, USA). Phenolic standards (gallic, $p$-hydroxybenzoic and cinnamic acids) and trolox (6hydroxy-2,5,7,8-tetramethylchroman-2-carboxylic acid) were purchased from Sigma (St. Louis, MO, USA). Mueller-Hinton agar (MH) and malt agar (MA) were obtained from the Institute of Immunology and Virology, Torlak (Belgrade, Serbia). Dimethylsulfoxide (DMSO), (Merck KGaA, Darmstadt, Germany) was used as a solvent. Methanol and all other chemicals and solvents were of analytical grade and 
purchased from common sources. Water was treated in a Milli-Q water purification system (TGI Pure Water Systems, Greenville, SC, USA).

\section{Chemical characterization}

\section{Macronutrients composition}

The samples were analysed for their nutritional chemical composition (protein, fat, carbohydrate and ash) through standard procedures. ${ }^{11}$ The crude protein content $(\mathrm{N} \times$ 4.38) of the samples was estimated by the macro-Kjeldahl method; crude fat was determined by extracting a known weight of powdered sample with petroleum ether, using a Soxhlet apparatus; ash content was determined by incineration at $600 \pm 15{ }^{\circ} \mathrm{C}$. Total carbohydrate was calculated by difference. Energy was calculated according to the following equation: Energy $(\mathrm{kcal})=4 \times(\mathrm{g}$ protein $+\mathrm{g}$ carbohydrate $)+9 \times(\mathrm{g}$ fat $)$.

\section{Hydrophilic compounds}

Free sugars. Free sugars were determined by a high performance liquid chromatograph (HPLC) system consisting of an integrated system with a pump (Knauer, Smartline system 1000, Berlin, Germany), degasser system (Smart line manager 5000) and an auto-sampler (AS-2057 Jasco, Easton, MD, USA), coupled to a refraction index detector (RI detector Knauer Smartline 2300) as previously described by the authors. $^{12,13}$ Sugars identification was undertaken by comparing the relative retention times of sample peaks with standards. Data were analyzed using Clarity 2.4 Software (DataApex, Podohradska, Czech Republic). Quantification was based on the RI signal response of each standard, using the internal standard (IS, raffinose) method and by using calibration curves obtained from the commercial standards of each compound. The results were expressed in g per $100 \mathrm{~g}$ of dry weight. 
Organic acids. Organic acids were determined following a procedure previously described by the authors. ${ }^{12,13}$ Analysis was performed using a Shimadzu 20A series UFLC (Shimadzu Corporation, Kyoto, Japan). Separation was achieved on an SphereClone (Phenomenex, Torrance, CA, USA) reverse phase $\mathrm{C}_{18}$ column (5 $\mu \mathrm{m}, 250$ $\mathrm{mm} \times 4.6 \mathrm{~mm}$ i.d) thermostatted at $35^{\circ} \mathrm{C}$. The elution was performed with sulphuric acid $3.6 \mathrm{mM}$ using a flow rate of $0.8 \mathrm{~mL} / \mathrm{min}$. Detection was carried out in a $\mathrm{DAD}$, using $215 \mathrm{~nm}$ and $245 \mathrm{~nm}$ (for ascorbic acid) as preferred wavelengths. The organic acids found were quantified by comparison of the area of their peaks recorded at 215 $\mathrm{nm}$ with calibration curves obtained from commercial standards of each compound. The results were expressed in g per $100 \mathrm{~g}$ of dry weight.

Phenolic acids and related compounds. Phenolic acid determination was performed using a Shimadzu 20A series ultra-fast liquid chromatograph (UFLC, Shimadzu Corporation, equipment described above) as previously described by the authors. ${ }^{12,13}$ Detection was carried out in a photodiode array detector (PDA), using $280 \mathrm{~nm}$ as the preferred wavelength. The phenolic acids were quantified by comparison of the area of their peaks recorded at $280 \mathrm{~nm}$ with calibration curves obtained from commercial standards of each compound. The absence of other phenolic compounds in the samples was confirmed using mass spectrometry. The results were expressed in mg per $100 \mathrm{~g}$ of dry weight.

\section{Lipophilic compounds}

Fatty acids. Fatty acids were determined after a trans-esterification procedure as described previously by the authors. ${ }^{12,13}$ The fatty acid profile was analyzed with a DANI 1000 gas chromatographer (GC) equipped with a split/splitless injector and a 
flame ionization detector (FID). Fatty acid identification was made by comparing the relative retention times of FAME peaks from samples with standards. The results were recorded and processed using Clarity 4.0.1.7 Software (DataApex, Podohradska, Czech Republic) and expressed in relative percentage of each fatty acid.

Tocopherols. Tocopherols were determined following a procedure previously described by the authors. ${ }^{12,13}$ Analysis was performed by HPLC (equipment described above), and a fluorescence detector (FP-2020; Jasco) programmed for excitation at $290 \mathrm{~nm}$ and emission at $330 \mathrm{~nm}$. The compounds were identified by chromatographic comparisons with authentic standards. Quantification was based on the fluorescence signal response of each standard, using the IS (tocol) method and by using calibration curves obtained from commercial standards of each compound. The results were expressed in $\mu \mathrm{g}$ per100 g of dry weight.

\section{Bioactivity evaluation}

\section{Extract preparation}

The lyophilized samples $(1 \mathrm{~g})$ were extracted by stirring with $40 \mathrm{~mL}$ of methanol for $1 \mathrm{~h}$ and subsequently filtered through Whatman No. 4 paper. The residue was then extracted with $20 \mathrm{~mL}$ of methanol for $1 \mathrm{~h}$. The combined methanolic extracts were evaporated at $40^{\circ} \mathrm{C}$ (rotary evaporator Büchi R-210, Büchi, Flawil, Switzerland) to dryness and redissolved in a) methanol for the antioxidant activity assays $(20 \mathrm{mg} / \mathrm{mL})$ and $b)$ a $5 \%$ solution of DMSO in distilled water for the antimicrobial activity assays (100 mg/mL).

\section{Antioxidant properties}

Successive dilutions were made from the stock solution and submitted to the in vitro assays already described by Reis et al. ${ }^{14}$, to evaluate the antioxidant activity of the 
samples. The sample concentrations $(\mathrm{mg} / \mathrm{mL})$ providing $50 \%$ of antioxidant activity or 0.5 of absorbance $\left(\mathrm{EC}_{50}\right)$ were calculated from the graphs of antioxidant activity percentages (DPPH, $\beta$-carotene/linoleate and TBARS assays) or absorbance at $690 \mathrm{~nm}$ (ferricyanide/Prussian blue assay) against sample concentrations. Trolox was used as a positive control.

Folin-Ciocalteu assay. One of the extract solutions $(5 \mathrm{mg} / \mathrm{mL}$ for the Portuguese sample and $1.25 \mathrm{mg} / \mathrm{mL}$ for the Serbian sample; $1 \mathrm{~mL}$ ) was mixed with Folin-Ciocalteu reagent ( $5 \mathrm{~mL}$, previously diluted with water $1: 10, \mathrm{v} / \mathrm{v})$ and sodium carbonate $(75 \mathrm{~g} / \mathrm{L}, 4 \mathrm{~mL})$. The tubes were vortex-mixed for $15 \mathrm{sec}$ and allowed to stand for $30 \mathrm{~min}$ at $40^{\circ} \mathrm{C}$ for colour development. Absorbance was then measured at $765 \mathrm{~nm}$ (Analytikjena spectrophotometer; Jena, Germany). Gallic acid was used to obtain the standard curve and the reduction of the Folin-Ciocalteu reagent by the samples was expressed as mg of gallic acid equivalents (GAE) per g of extract.

Ferricyanide/Prussian blue assay. The extract solutions with different concentrations $(0.5 \mathrm{~mL})$ were mixed with sodium phosphate buffer $(200 \mathrm{mmol} / \mathrm{L}, \mathrm{pH} 6.6,0.5 \mathrm{~mL})$ and potassium ferricyanide $(1 \% \mathrm{w} / \mathrm{v}, 0.5 \mathrm{~mL})$. The mixture was incubated at $50^{\circ} \mathrm{C}$ for 20 min and trichloroacetic acid $(10 \% \mathrm{w} / \mathrm{v}, 0.5 \mathrm{~mL})$ was added. The mixture $(0.8 \mathrm{~mL})$ was poured in the 48 wells plate, the same with deionised water $(0.8 \mathrm{~mL})$ and ferric chloride $(0.1 \% \mathrm{w} / \mathrm{v}, 0.16 \mathrm{~mL})$, and the absorbance was measured at $690 \mathrm{~nm}$ in ELX800 Microplate Reader (Bio-Tek Instruments, Inc; Winooski, VT, USA).

DPPH radical-scavenging activity. This methodology was performed using the Microplate Reader mentioned above. The reaction mixture in each of the 96-well of the plate consisted of one of the different concentrations of the extracts $(30 \mu \mathrm{l})$ and 
methanolic solution $(270 \mu \mathrm{L})$ containing DPPH radicals $\left(6 \times 10^{-5} \mathrm{~mol} / \mathrm{L}\right)$. The mixture was left to stand for $30 \mathrm{~min}$ in the dark and the absorption was measured at $515 \mathrm{~nm}$. The radical scavenging activity (RSA) was calculated as a percentage of DPPH discoloration using the equation: $\% \mathrm{RSA}=\left[\left(\mathrm{A}_{\mathrm{DPPH}}-\mathrm{A}_{\mathrm{S}}\right) / \mathrm{A}_{\mathrm{DPPH}}\right] \times 100$, where $\mathrm{A}_{\mathrm{S}}$ is the absorbance of the solution containing the sample, and $\mathrm{A}_{\mathrm{DPPH}}$ is the absorbance of the DPPH solution.

Inhibition of $\beta$-carotene bleaching or $\beta$-carotene/linoleate assay. A solution of $\beta$ carotene was prepared by dissolving $\beta$-carotene $(2 \mathrm{mg})$ in chloroform $(10 \mathrm{~mL})$. Two millilitres of this solution were pipetted into a round-bottom flask. The chloroform was removed at $40^{\circ} \mathrm{C}$ under vacuum and linoleic acid (40 mg), Tween 80 emulsifier (400 $\mathrm{mg})$, and distilled water $(100 \mathrm{~mL})$ were added to the flask with vigorous shaking. Aliquots $(4.8 \mathrm{~mL})$ of this emulsion were transferred into test tubes containing extract solutions with different concentrations $(0.2 \mathrm{~mL})$. The tubes were shaken and incubated at $50^{\circ} \mathrm{C}$ in a water bath. As soon as the emulsion was added to each tube, the zero time absorbance was measured at $470 \mathrm{~nm}$. $\beta$-Carotene bleaching inhibition was calculated using the following equation: (Absorbance after $2 \mathrm{~h}$ of assay/ initial absorbance) $\times 100$.

Thiobarbituric acid reactive substances (TBARS) assay. Porcine (Sus scrofa) brains were obtained from official slaughtered animals, dissected, and homogenized with Polytron in an ice cold Tris- $\mathrm{HCl}$ buffer $(20 \mathrm{mM}, \mathrm{pH} 7.4)$ to produce a 1:2 w/v brain tissue homogenate which was centrifuged at $3000 \mathrm{~g}$ for $10 \mathrm{~min}$. An aliquot $(100 \mu \mathrm{L})$ of the supernatant was incubated with the different concentrations of the sample solutions $(200 \mu \mathrm{L})$ in the presence of $\mathrm{FeSO}_{4}(10 \mathrm{mM} ; 100 \mu \mathrm{L})$ and ascorbic acid $(0.1 \mathrm{mM} ; 100$ $\mu \mathrm{L})$ at $37^{\circ} \mathrm{C}$ for $1 \mathrm{~h}$. The reaction was stopped by the addition of trichloroacetic acid $(28 \% \mathrm{w} / \mathrm{v}, 500 \mu \mathrm{L})$, followed by thiobarbituric acid (TBA, 2\%, w/v, $380 \mu \mathrm{L})$ and the mixture was then heated at $80^{\circ} \mathrm{C}$ for $20 \mathrm{~min}$. After centrifugation at $3000 \mathrm{~g}$ for $10 \mathrm{~min}$ 
to remove the precipitated protein, the colour intensity of the malondialdehyde (MDA)TBA complex in the supernatant was measured by its absorbance at $532 \mathrm{~nm}$. The inhibition ratio (\%) was calculated using the following formula: Inhibition ratio $(\%)=$ $[(\mathrm{A}-\mathrm{B}) / \mathrm{A}] \times 100 \%$, where $\mathrm{A}$ and $\mathrm{B}$ were the absorbance of the control and the sample solution, respectively.

\section{Antimicrobial properties}

Successive dilutions were made from the DMSO:water stock solution and submitted to antibacterial and antifungal assays.

Antibacterial activity. The following Gram-negative bacteria: Escherichia coli (ATCC 35210), Pseudomonas aeruginosa (ATCC 27853), Salmonella typhimurium (ATCC 13311), Enterobacter cloacae (ATCC 35030), and Gram-positive bacteria: Staphylococcus aureus (ATCC 6538), Bacillus cereus (clinical isolate), Micrococcus flavus (ATCC 10240), and Listeria monocytogenes (NCTC 7973) were used. The microorganisms were obtained from the Mycological Laboratory, Department of Plant Physiology, Institute for Biological Research "Siniša Stanković", University of Belgrade, Serbia.

The minimum inhibitory (MIC) and minimum bactericidal (MBC) concentrations were determined by the microdilution method. ${ }^{15}$ Briefly, a fresh overnight culture of bacteria was adjusted by the spectrophotometer to a concentration of $1 \times 10^{5} \mathrm{CFU} / \mathrm{mL}$. The requested $\mathrm{CFU} / \mathrm{mL}$ corresponded to a bacterial suspension determined in a spectrophotometer at $625 \mathrm{~nm}$ (OD625). Dilutions of inoculate were cultured on solid medium to verify the absence of contamination and check the validity of the inoculum. Different solvent dilutions of methanolic extract were carried out over the wells containing $100 \mu \mathrm{L}$ of Tryptic Soy Broth (TSB) and thereafter, $10 \mu \mathrm{L}$ of inoculum was 
added to all of the wells. The microplates were incubated for $24 \mathrm{~h}$ at $37^{\circ} \mathrm{C}$. The MIC of the samples was detected following the addition of $40 \mu \mathrm{L}$ of iodonitrotetrazolium chloride (INT) $(0.2 \mathrm{mg} / \mathrm{mL})$ and incubation at $37^{\circ} \mathrm{C}$ for $30 \mathrm{~min}$. The lowest concentration which produced a significant inhibition (around 50\%) of the growth of the bacteria in comparison with the positive control was identified as the MIC. The minimum inhibitory concentrations (MICs) obtained from the susceptibility testing of various bacteria to tested extract were also determined by a colorimetric microbial viability assay based on reduction of a INT colour and compared with positive control for each of the bacterial strains. ${ }^{16,17} \mathrm{MBC}$ was determined by serial sub-cultivation of 10 $\mu \mathrm{L}$ into microplates containing $100 \mu \mathrm{L}$ of TSB. The lowest concentration which showed no growth after this sub-culturing was read as the MBC. Standard drugs, namely streptomycin and ampicillin were used as positive controls. 5\% DMSO was used as negative control.

Antifungal activity. For the antifungal bioassays, the following microfungi were used: Aspergillus fumigatus (1022), Aspergillus ochraceus (ATCC 12066), Aspergillus versicolor (ATCC 11730), Aspergillus niger (ATCC 6275), Penicillium funiculosum (ATCC 36839), Penicillium ochrochloron (ATCC 9112), Trichoderma viride (IAM 5061), and Penicillium verrucosum var. cyclopium (food isolate). The organisms were obtained from the Mycological Laboratory, Department of Plant Physiology, Institute for Biological Research "Siniša Stanković'”, Belgrade, Serbia. The micromycetes were maintained on malt agar (MA) and the cultures were stored at $4{ }^{\circ} \mathrm{C}$ and subcultured once a month. ${ }^{18}$

The fungal spores were washed from the surface of agar plates with sterile $0.85 \%$ saline containing $0.1 \%$ Tween $80(\mathrm{v} / \mathrm{v})$. The spore suspension was adjusted with sterile saline to a concentration of approximately $1.0 \times 10^{5}$ in a final volume of $100 \mu \mathrm{L} /$ well. The 
inoculums were stored at $4{ }^{\circ} \mathrm{C}$ for further use. Dilutions of the inoculums were cultured on solid MA to verify the absence of contamination and to check the validity of the inoculum.

Minimum inhibitory concentrations (MICs) determination was performed by a serial dilution technique using 96-well microtitre plates. The investigated extract was dissolved in 5\% solution of DMSO and added to broth malt medium with fungal inoculum. The microplates were incubated for $72 \mathrm{~h}$ at $28^{\circ} \mathrm{C}$. The lowest concentrations without visible growth (at the binocular microscope) were defined as MIC. The minimum fungicidal concentrations (MFCs) were determined by serial sub-cultivation of $2 \mu \mathrm{L}$ in microtitre plates containing $100 \mu \mathrm{L}$ of malt broth per well and further incubation for $72 \mathrm{~h}$ at $28^{\circ} \mathrm{C}$. The lowest concentration with no visible growth was defined as the MFC, indicating 99.5\% killing of the original inoculum. $5 \%$ DMSO was used as a negative control, while bionazole and ketokonazole were used as positive controls.

\section{Statistical analysis}

Three samples were used and all assays were carried out in triplicate. The results are expressed as mean values and standard deviation (SD). The results were analysed using one-way analysis of variance (ANOVA) followed by Tukey's HSD Test with $\alpha=0.05$. This analysis was carried out using SPSS v. 20.0 program.

\section{Results and discussion}

\section{Chemical composition}

As referred above, all assays were performed for both samples (Portuguese and Serbian) and the results were compared with each other. Concerning the nutritional value of the 
samples (Table 1), the Portuguese one revealed higher protein $(14.78 \mathrm{~g} / 100 \mathrm{~g} \mathrm{dw})$ and fat contents $(3.74 \mathrm{~g} / 100 \mathrm{~g} \mathrm{dw})$; however, the highest content of carbohydrates was detected in the Serbian sample $(81.42 \mathrm{~g} / 100 \mathrm{~g} \mathrm{dw})$. The Portuguese species also revealed the highest energy contribution $(386.74 \mathrm{kcal} / 100 \mathrm{~g} \mathrm{dw})$ compared with the species from Serbia $(359.81 \mathrm{kcal} / 100 \mathrm{~g} \mathrm{dw})$. The results obtained are in agreement with the literature, since carbohydrates and proteins are the two main components of mushroom fruiting bodies, the first constituting about half the mushroom dry matter, ${ }^{19,20}$ proving that mushrooms could be considered valuable nutritional and healthy foods, since they are rich in proteins and minerals and poor in calories and fat.

The free sugars composition is presented in Table 2. Free sugars composition goes beyond its part in simply characterising the chemical constitution of the mushroom species in question. It also provides us with some additional information which allows us to classify the mushroom as a functional food (source of nutraceuticals mono/oligosaccharides). In this study, both species (from both origins) revealed the presence of fructose, mannitol and trehalose, with no significant differences between the total free sugars content $(12.68 \mathrm{~g} / 100 \mathrm{~g}$ dw for the Portuguese sample and $12.77 \mathrm{~g} / 100 \mathrm{~g}$ $\mathrm{dw}$ for the Serbian sample).

Mannitol, like the polyols in general, has practically no influence on blood glucose concentrations. After polyols consumption, they remain in low concentrations in blood because of their slow and incomplete absorption, and specifically mannitol is absorbed and eliminated almost unchanged via the kidneys. ${ }^{21}$ Mannitol also has some medicinal applications mainly due to its osmotic diuretic properties. ${ }^{22}$ Some bioactive effects have been attributed to trehalose, such as suppressing the auto-oxidation of unsaturated fatty acids. $^{23}$ This capability becomes important not only from the standpoint of food preservation but also for human health, since the oxidation products of lipids can be detrimental and associated with the aging process. 
With these aspects in mind, mushrooms, and in this case $S$. granulatus, proved to be a source of nutraceuticals, namely mono- and disaccharides as well as polyols. These findings are in agreement with other studies from our research group which have already identified some wild species from Portugal and Serbia as a source of such molecules. ${ }^{24,25}$ Mannitol and trehalose are the main representatives of alcoholic sugars and oligosaccharides usually found in mushrooms, and the mean values described in wild mushrooms generally vary between 2.89 and $3.92 \mathrm{~g} / 100 \mathrm{~g} \mathrm{dw}$, respectively. ${ }^{20}$ The results obtained in the present work are similar to those described in the literature, since we obtained mean values of $3.26 \mathrm{~g} / 100 \mathrm{~g} \mathrm{dw}$ for mannitol and $3.72 \mathrm{~g} / 100 \mathrm{~g} \mathrm{dw}$ for trehalose.

Concerning the organic acid composition (Table 2), both studied species revealed no significant differences between the total organic acids presented $(4.63 \mathrm{~g} / 100 \mathrm{~g} \mathrm{dw}$ for the Portuguese sample and $4.44 \mathrm{~g} / 100 \mathrm{~g}$ dw for the Serbian sample). Nevertheless, both profiles were somewhat different. The Portuguese sample contained oxalic acid (3.35 $\mathrm{g} / 100 \mathrm{~g} \mathrm{dw})$, quinic acid $(0.36 \mathrm{~g} / 100 \mathrm{~g} \mathrm{dw})$ and fumaric acid $(0.92 \mathrm{~g} / 100 \mathrm{~g} \mathrm{dw})$. On the other hand, the sample from Serbia was composed of oxalic acid $(0.42 \mathrm{~g} / 100 \mathrm{~g} \mathrm{dw})$, malic acid $(0.94 \mathrm{~g} / 100 \mathrm{~g} \mathrm{dw})$, citric acid $(1.77 \mathrm{~g} / 100 \mathrm{~g} \mathrm{dw})$ and fumaric acid $(1.31 \mathrm{~g} / 100$ g dw). Other studies in S. granulatus identified oxalic, aconitric, citric, malic, quinic, succinic, shikimic and fumaric acids, with succinic and shikimic acids appearing in lower quantities. ${ }^{10,26}$ These results support the idea that the chemical content among species from different sources can be similar, as a characteristic of the species, but the chemical profile may vary between them. Although morphologically similar, fungi metabolites may be very different. Some metabolites may be produced by all the varieties of a particular species, while others may be specific metabolites of an organism. It should be noted that the chemistry of an organism may also vary according to the conditions under which it develops. ${ }^{27}$ As we demonstrate, the total organic acid 
levels have no significant differences between the species, but we found different profiles (e.g. quinic acid was only found in the Portuguese sample, while malic and citric acids were observed in the Serbian sample). Although organic acids are considered non-nutrients, they constitute important molecules given their biological activities. Malic, citric, and fumaric acids, in addition to playing an important role in the Krebs cycle which is essential for human metabolism, have many other applications. Malic acid has been reported as having a bactericidal effect, ${ }^{28}$ being employed in food additives as well as polymer and pharmaceutical industries. ${ }^{29}$ Citric acid (known for its antioxidant activity) is also a crystal thickener in bones ${ }^{30}$ while fumaric acid is effective against psoriasis and inflammation, and can be used potentially as a neuro and chemoprotector. ${ }^{31,32}$ Due to its properties, oxalic acid constitutes part of pharmaceutical preparations and is used for desloughing wounds and ulcers, ${ }^{33}$ while quinic acid is a stronger antioxidant..$^{34}$

Analysing the results obtained for the phenolic acids detected in the studied samples (Table 2), we can conclude that the Portuguese sample showed a higher content of these compounds $(0.59 \mathrm{mg} / 100 \mathrm{~g} \mathrm{dw})$ compared with the Serbian samples $(0.13 \mathrm{mg} / 100 \mathrm{~g}$ $\mathrm{dw})$. The former, was the only sample that revealed the presence of gallic acid $(0.11$ $\mathrm{mg} / 100 \mathrm{~g} \mathrm{dw})$. On the other hand, $p$-hydroxybenzoic acid was present both in the Portuguese and Serbian samples $(0.48 \mathrm{mg} / 100 \mathrm{~g} \mathrm{dw}$ and $0.13 \mathrm{mg} / 100 \mathrm{~g} \mathrm{dw}$, respectively) as also the related compound cinnamic acid $(0.13 \mathrm{mg} / 100 \mathrm{~g} \mathrm{dw}$ and 0.03 $\mathrm{mg} / 100 \mathrm{~g} \mathrm{dw}$, respectively). Phenolic acids hold antioxidant activity as chelators and free radical scavengers with particular effects on hydroxyl and peroxyl radicals, superoxide anions and peroxynitrites. Curiously, one of the most studied and promising phenolic compound is gallic acid (detected in the Portuguese sample) which is a compound belonging to the hydroxybenzoic acids group. ${ }^{35}$ Other phenolics have been identified in S. granulatus from Portugal, namely quercetin $(0.2-1.59 \mathrm{mg} / 100 \mathrm{~g} \mathrm{dw}){ }^{26}$ 
These results support the idea that since mushrooms obtain nutrients by absorption, they are greatly influenced by the environment in which they develop, with this influence being translated on their secondary metabolites. Given these results, we can conclude that besides being a source of nutraceuticals, mushrooms are also a source of bioactive compounds, namely phenolic acids. In fact, mushrooms have been described as a source of these compounds. ${ }^{14,36}$

Analysing the results obtained for the fatty acids profile (Table 3), we can conclude that mushrooms are a good source of "good fats", namely mono- and polyunsaturated fatty acids (MUFA and PUFA, respectively). Actually, these were the prevailing fatty acids in both samples $(21.30 \%-64.40 \%$ of total FA). The Portuguese sample revealed a higher content in MUFA (26.55\% of total FA) while the Serbian sample showed the highest content in PUFA (64.40\% of total FA). Both samples showed a very similar profile with the prevalence of the saturated fatty acids (SFA) palmitic acid (C16:0) and stearic acid (C18:0), the MUFA oleic acid (C18:1n9), and the PUFA linoleic acid (C18:2n6). These results are also in agreement with literature which reported palmitic, oleic, linoleic, stearic and linolenic (C18:3n3) acids as the major fatty acids found in wild mushrooms, with the latter two found in smaller percentages. ${ }^{19}$ There are studies on the fatty acids profile of $S$. granulatus from Portugal. ${ }^{9}$ These authors reported that the main fatty acids presented by the studied species were palmitic acid, palmitoleic acid, stearic acid, oleic acid and linoleic acid; higher contents of MUFA and PUFA than SFA were also illustrated. By comparing both studies, where the analysed species was collected in the same region of Portugal but in different seasons/years, we can conclude that the generic profile remains, although we can verify some fluctuations. This is further evidence that although certain compounds may be characteristic of a particular species, mushrooms are highly influenced by their environment (temperature, moisture, pH). Accordingly, although palmitic acid (a nutritionally undesirable SFA) and the 
nutritional neutral saturated stearic acid are some of the mushrooms major fatty acids, this matrix continues to be a source of nutraceuticals, as oleic and linoleic acids were detected in higher percentages. Of interest is the observation that oleic acid has been referred to reduce coronary heart disease risk by $20-40 \%$ mainly via LDL-cholesterol reduction as well as having other beneficial effects on risk factors for cardiovascular disease. $^{37,38}$ Linoleic acid, an omega-6 PUFA has also been shown to reduce the risk of coronary heart disease. ${ }^{39}$ Given the biological activities of this fatty acid found in the studied mushroom species, we can consider them a source of molecules with health benefits.

Concerning vitamin E, the Portuguese sample revealed the highest content of this vitamin's isoforms $(294.94 \mu \mathrm{g} / 100 \mathrm{~g} \mathrm{dw}$; Table 3). This sample presented the highest levels of $\alpha$-tocopherol $(17.86 \mu \mathrm{g} / 100 \mathrm{~g} \mathrm{dw})$ and mostly of $\delta$-tocopherol $(101.79 \mu \mathrm{g} / 100$ $\mathrm{g} \mathrm{dw}) . \beta$-tocopherol was the prevailing isoform in both samples, and its content was similar between Portuguese and Serbian samples $(175.29 \mu \mathrm{g} / 100 \mathrm{~g} \mathrm{dw}$ and 179.68 $\mu \mathrm{g} / 100 \mathrm{~g} \mathrm{dw}$, respectively). Vitamin $\mathrm{E}$, as an antioxidant, exerts an important role in lipid peroxidation. Indeed, it is the only major lipid-soluble, chain breaking antioxidant found in plasma, red cells and tissues, allowing it to protect the integrity of lipid structures, mainly membranes. ${ }^{35}$ Because of its function, the consumption of food where this vitamin is present takes on added importance. Similar patterns have been detected in different species of mushrooms both from Portugal and Serbia. ${ }^{13,24}$

\section{Bioactive properties}

Wild mushrooms have also been referred to as having bioactive properties, namely antioxidant $^{36}$ and antimicrobial ${ }^{40}$ potential. For this reason, antioxidant and antimicrobial properties of the studied mushroom species were also evaluated. 
The response of antioxidants to different radical or oxidant sources may differ. Consequently, no single assay accurately reflects the mechanism of action of all radical sources or all antioxidants in a complex system. ${ }^{41}$ Therefore, the antioxidant activity of the studied mushrooms was assessed by resorting to five different methods (Table 4). The Serbian sample revealed the most promising results since, in general, this sample revealed the highest antioxidant properties. It showed the highest reducing power, with the highest content in total phenolics assessed through the Folin-Ciocalteu assay (44.36 mg GAE/g extract) and the lowest $\mathrm{EC}_{50}$ value for the Ferricyanide/Prussian blue assay (0.41 $\mathrm{mg} / \mathrm{mL})$. It also revealed the highest radical scavenging activity, evaluated through the DPPH radical-scavenging activity assay $(0.89 \mathrm{mg} / \mathrm{mL})$ and the highest lipid peroxidation inhibition assessed through the TBARS assay $(0.02 \mathrm{mg} / \mathrm{mL})$. The exception was verified with the evaluation of the lipid peroxidation inhibition measured through the $\beta$-carotene/linoleate assay, where both samples presented similar $\mathrm{EC}_{50}$ values with no significant differences between them $(0.45$ and $0.48 \mathrm{mg} / \mathrm{mL})$. Some studies report the antioxidant activity of $S$. granulatus. ${ }^{26}$ In that study, S. granulatus revealed moderated antioxidant potential, only evaluated through the DDPH radical scavenging activity. ${ }^{26}$

The antioxidant properties of several matrices present in the human diet, such as mushrooms, must be assigned to the bioactive molecules obtainable from them. These molecules include vitamins (e.g. C and E), flavonoids and other phenolic compounds, or carotenoids. ${ }^{35}$ Although in general the Portuguese sample revealed higher levels of vitamin E isoforms $(294.94 \mu \mathrm{g} / 100 \mathrm{~g} \mathrm{dw})$ and phenolic acids $(0.59 \mathrm{mg} / 100 \mathrm{~g} \mathrm{dw})$, the Serbian sample showed greater antioxidant capacity. This implies that these are not the only molecules that are contributing to the activity. Others that were not identified could also be involved (e.g. steroids or polysaccharides). 
Mushrooms have also been exploited as an alternative source of novel antimicrobials, and according to the literature, mushroom extracts generally exhibit higher antimicrobial activity against gram-positive bacteria. ${ }^{40}$ These studies are interesting, not only from the standpoint of the discovery of new extracts/molecules with antimicrobial potential, but also from their inclusion as food additives (preservatives), as our research group has been demonstrating. ${ }^{25}$ Therefore, the antimicrobial potential of the studied species can also contribute to increasing foods' shelf life.

The results regarding the antimicrobial properties of the samples are presented in Tables 5 and 6. Concerning the antibacterial activity (Table 5) generally, the Serbian sample revealed better results (MIC: $0.04-0.15 \mathrm{mg} / \mathrm{mL}$ and MBC: $0.05-0.2 \mathrm{mg} / \mathrm{mL}$ ). Both samples showed bioactivity towards all the Gram positive and Gram negative bacteria used, and in general, the values obtained were lower than those presented by the standards streptomycin and ampicillin. Furthermore, both species also revealed antifungal properties (Table 6) against all the strains tested. Again, the Serbian sample registered the lowest MIC and MBC values. However, in this case, the Portuguese sample revealed similar results for the species Aspergillus niger, Penicillium funiculosum, P. ochrochloron and P. verrucosum var. cyclopium. Again, the values displayed by the samples (MIC: $0.025-0.45 \mathrm{mg} / \mathrm{mL}$; MFC: $0.05-0.8 \mathrm{mg} / \mathrm{mL}$ ) were generally lower than those of the standards (MIC: $0.1-1.0$; MFC: $0.2-1.5 \mathrm{mg} / \mathrm{mL}$ ).

\section{Conclusions}

This work aims to be a step forward towards classifying mushrooms, specifically Suillus granulatus as a functional food. It provides new data concerning the chemical characterisation of the species from the perspective of being a source of nutraceuticals and bioactive compounds. Throughout the study, it was established that this mushroom 
could be classified as a valuable health food, rich in carbohydrates and proteins and low in fat. It is also an excellent source of a wide range of interesting molecules, namely nutraceuticals such as unsaturated fatty acids, free sugars and vitamin E. S. granulatus proved to have antioxidant and antimicrobial properties irrespective of its origin. This way, this wild species can be consumed in either of these countries with beneficial effects.

In conclusion, Suillus granulatus can be considered a functional food, since the molecules found therein have, besides the nutritional effect, beneficial properties such as antioxidant and antimicrobial activity. However, further in-depth studies such as the study of the compounds' mechanism of action in vitro and in vivo, need further quantification.

\section{Competing interests}

The authors declare no competing financial interest.

\section{Acknowledgements}

The authors are grateful to Foundation for Science and Technology (FCT, Portugal) and COMPETE/QREN/EU for the financial support of the CIMO strategic project PEstOE/AGR/UI0690/2011 and of the contract of L. Barros. The authors also thank to the Serbian Ministry of Education, Science and Technological Development for financial support (grant number 173032). The authors thank Dr. Maria João Sousa for the harvest of the Portuguese samples.

\section{References}

1 S.M. Alzamora, D. Salvatori, S.M. Tapia, A. López-Malo, J. Welti-Chanes, P. Fito, J. Food Eng., 2005, 67, 205-214. 
2 EU, Luxembourg: Publications Office of the European Union, 2010, ISBN 97892-79-14239-0.

3 A.T. Diplock, P.J. Aggett, M. Ashwell, F. Bornet, E.B. Fern, M.B. Roberfroid, Brit. J. Nutr., 1999, 81, 1-27.

4 R. Chadwick, Funct. Foods. Germany: Springer, 2013.

5 V.S. Evenson, Denver, Colorado: Big Earth Publishing, 1997.

6 M. Eppinger, New Holland Publishers, 2006.

7 K. Cullings, G. Ishkhanova, G. Ishkhanov, J. Henson, Soil Biol. Biochem., 2010, 42, 1176-1178.

8 Z.J. Dong, F. Wang, R.R. Wang, L.M. Yang, Y.T. Zheng, J.K. Liu, Chin. Trad. Herbal Drugs, 2007, 38, 17-19.

9 B. Ribeiro, P.G. de Pinho, P.B. Andrade, P. Baptista, P. Valentão, Microchem. J., 2009, 93, 29-35.

10 B. Ribeiro, R. Lopes, P.B. Andrade, R.M. Seabra, R.F. Gonçalves, P. Baptista, I. Quelhas, P. Valentão, Food Chem., 2008, 110, 47-56.

11 AOAC. $19^{\text {th }}$ ed., Gaithersburg, MD, USA: AOAC INTERNATIONAL, 2012.

12 D. Stojković, F.S. Reis, L. Barros, J. Glamočlija, A. Ćirić, L.J.I.D. van Griensven, M. Soković, I.C.F.R. Ferreira, Food Chem Toxicol., 2013, 59, 289296.

13 F.S. Reis, L. Barros, R.C. Calhelha, A. Ćirić, L.J.L.D. van Griensven, M. Soković, I.C.F.R. Ferreira, Food Chem. Toxicol., 2013 62, 91-98.

14 F.S. Reis, A. Martins, L. Barros, I.C.F.R. Ferreira, Food Chem. Toxicol., 2012a, 50, 1201-1207.

15 A. Espinel-Ingroff, J. Clin. Microbiol., 2001, 39, 1360-1367.

16 Clinical and Laboratory Standards Institute $\left(8^{\text {th }}\right.$ ed.) Wayne, PA: CLSI publication M07-A8. Clinical and Laboratory Standards Institute, 2009. 
17 T. Tsukatani, H. Suenaga, M. Shiga, K. Noguchi, M. Ishiyama, T. Ezoe, K. Matsumoto, J. Microbiol. Method, 2012, 90, 160-166.

18 C. Booth, In J. R. Norris \& D. W. Ribbons (Eds.), London and New York: Academic Press, 1971, 49-94.

19 P. Kalač, Food Chem., 2009, 113, 9-16.

20 P. Kalač, J. Sci. Food Agric., 2013, 93, 209-218.

21 T.H. Grenby, United Kingdom: Blackie Academic \& Professional, Springer, 1996.

22 H. Shawkat, M.-M. Westwood, A. Mortimer, Cont Educ Anaesth Crit Care Pain, $2012,12,82-85$

23 T. Higashiyama, Pure Appl. Chem., 2002, 74, 1263-1269.

24 E. Pereira, L. Barros, A. Martins, I.C.F.R. Ferreira, Food Chem., 2012, 130, 394-403.

25 F.S. Reis, D. Stojković, M. Soković, J. Glamočlija, A. Ćirić, L. Barros, I.C.F.R. Ferreira, Food Res. Int., 2012b, 48, 620-626.

26 B. Ribeiro, J. Rangel, P. Valentão, P. Baptista, R.M. Seabra, P.B. Andrade, J. Agric. Food Chem., 2006, 54, 8530-8537.

27 J.R. Hanson, United Kingdom: Royal Society of Chemistry, 2008.

28 R.M. Raybaudi-Massilia, J. Mosqueda-Melgar, O. Martín-Belloso, Food Control, 2009, 20, 105-112.

29 M. Nagarajkumar, J. Jayaraj, S. Muthukrishnan, R. Bhaskaran, R. Velazhahan, Microbiol. Res., 2005, 160, 291-298.

30 Y.Y. Hu, A. Rawal, K. Schmidt-Rohr, Proceed. Natl. Acad. Sci., 2010, 107, $22425-22429$.

31 P.J. Altmeyer, U. Mattlies, F. Pawlak, K. Hoffmann, P.J. Frosch, P. Ruppert, et al., J. Am. Acad. Derm., 1994, 30, 977-981. 
32 T. Baati, P. Horcajada, R. Gref, P. Couvreur, C.J. Serre, Pharm. Biomed. Anal., 2011, 56, 758-762.

33 H.Z. Lian, L. Mao, X.L. Ye, J. Miao, J. Pharm. Biomed. Anal., 1999, 19, 621 625.

34 T.M. Hung, M.K. Na, P.T. Thuong, N.D. Su, D.E. Sok, K.S. Song, Y.H. Seong, K.H. Bae, J. Ethnopharm., 2006, 108, 188-192.

35 M. Carocho, I.C.F.R. Ferreira, Food Chem. Toxicol., 2013, 51, 15-25.

36 I.C.F.R. Ferreira, L. Barros, R.M.V. Abreu, Curr. Med. Chem., 2009, 16, 15431560.

37 P.M. Kris-Etherton, Circulation, 1999, 100, 1253-8.

38 E. Lopez-Huertas, Pharmacol. Res., 2010, 61, 200-207.

39 W.S. Harris, D. Mozaffarian, E. Rimm, P. Kris-Etherton, L.L. Rudel, L.J. Appel, M.M. Engler, M.B. Engler, F. Sacks, Circulation, 2009, 119, 902-907.

40 M.J. Alves, I.C.F.R. Ferreira, J. Dias, V. Teixeira, A. Martins, M. Pintado, Planta Medica, 2012, 78, 1707-1718.

41 R.L. Prior, X. Wu, K. Schaich, J. Agric. Food Chem., 2005, 53, 4290-4302. 
Table 1. Nutritional value (mean \pm SD).

\begin{tabular}{lcc}
\hline & \multicolumn{2}{c}{ Suillus granulatus $(\mathrm{L}$.$) Roussel$} \\
\cline { 2 - 3 } & Portugal & Serbia \\
\hline Ash $(\mathrm{g} / 100 \mathrm{~g} \mathrm{dw})$ & $7.99 \pm 0.91^{\mathrm{b}}$ & $10.38 \pm 0.08^{\mathrm{a}}$ \\
Proteins $(\mathrm{g} / 100 \mathrm{~g} \mathrm{dw})$ & $14.78 \pm 0.41^{\mathrm{a}}$ & $7.93 \pm 0.00^{\mathrm{b}}$ \\
Fat $(\mathrm{g} / 100 \mathrm{~g} \mathrm{dw})$ & $3.74 \pm 0.20^{\mathrm{a}}$ & $0.27 \pm 0.09^{\mathrm{b}}$ \\
Carbohydrates $(\mathrm{g} / 100 \mathrm{~g} \mathrm{dw})$ & $73.49 \pm 0.46^{\mathrm{b}}$ & $81.42 \pm 0.01^{\mathrm{a}}$ \\
Energy $(\mathrm{kcal} / 100 \mathrm{~g} \mathrm{dw})$ & $386.74 \pm 3.26^{\mathrm{a}}$ & $359.81 \pm 0.58^{\mathrm{b}}$ \\
\hline
\end{tabular}

Different letters in each row indicate significant differences between the samples $(p<0.05)$. dwdry weight. 
Table 2. Hydrophilic compounds (mean \pm SD).

\begin{tabular}{lcc}
\hline & \multicolumn{2}{c}{ Suillus granulatus $(\mathrm{L}$.$) Roussel$} \\
\hline & Portugal & Serbia \\
\hline Fructose $(\mathrm{g} / 100 \mathrm{~g} \mathrm{dw})$ & $4.49 \pm 0.02^{\mathrm{b}}$ & $7.02 \pm 0.16^{\mathrm{a}}$ \\
Mannitol $(\mathrm{g} / 100 \mathrm{~g} \mathrm{dw})$ & $3.33 \pm 0.10^{\mathrm{a}}$ & $3.18 \pm 0.14^{\mathrm{a}}$ \\
Trehalose $(\mathrm{g} / 100 \mathrm{~g} \mathrm{dw})$ & $4.86 \pm 0.06^{\mathrm{a}}$ & $2.57 \pm 0.13^{\mathrm{b}}$ \\
Total frees sugars $(\mathrm{g} / 100 \mathrm{~g} \mathrm{dw})$ & $12.68 \pm 0.01^{\mathrm{a}}$ & $12.77 \pm 0.42^{\mathrm{a}}$ \\
\hline Oxalic acid $(\mathrm{g} / 100 \mathrm{~g} \mathrm{dw})$ & $3.35 \pm 0.16^{\mathrm{a}}$ & $0.42 \pm 0.02^{\mathrm{b}}$ \\
Quinic acid $(\mathrm{g} / 100 \mathrm{~g} \mathrm{dw})$ & $0.36 \pm 0.02$ & $\mathrm{nd}$ \\
Malic acid $(\mathrm{g} / 100 \mathrm{~g} \mathrm{dw})$ & $\mathrm{nd}$ & $0.94 \pm 0.16$ \\
Citric acid $(\mathrm{g} / 100 \mathrm{~g} \mathrm{dw})$ & $\mathrm{nd}$ & $1.77 \pm 0.25$ \\
Fumaric acid $(\mathrm{g} / 100 \mathrm{~g} \mathrm{dw})$ & $0.92 \pm 0.00^{\mathrm{b}}$ & $1.31 \pm 0.03^{\mathrm{a}}$ \\
Total organic acids $(\mathrm{g} / 100 \mathrm{~g} \mathrm{dw})$ & $4.63 \pm 0.14^{\mathrm{a}}$ & $4.44 \pm 0.09^{\mathrm{a}}$ \\
\hline Gallic acid $(\mathrm{mg} / 100 \mathrm{~g} \mathrm{dw})$ & $0.11 \pm 0.01$ & $\mathrm{nd}$ \\
$p$-Hydroxybenzoic acid $(\mathrm{mg} / 100 \mathrm{~g} \mathrm{dw})$ & $0.48 \pm 0.00^{\mathrm{a}}$ & $0.13 \pm 0.01^{\mathrm{b}}$ \\
Total phenolic acids $(\mathrm{mg} / 100 \mathrm{~g} \mathrm{dw})$ & $0.59 \pm 0.01^{\mathrm{a}}$ & $0.13 \pm 0.01^{\mathrm{b}}$ \\
Cinnamic acid $(\mathrm{mg} / 100 \mathrm{~g} \mathrm{dw})$ & $0.13 \pm 0.00^{\mathrm{a}}$ & $0.03 \pm 0.00^{\mathrm{b}}$ \\
\hline
\end{tabular}

Different letters in each row indicate significant differences between the samples $(p<0.05)$. dwdry weight; nd- not detected. 
Table 3. Lipophilic compounds (mean \pm SD).

\begin{tabular}{|c|c|c|}
\hline & \multicolumn{2}{|c|}{ Suillus granulatus (L.) Roussel } \\
\hline Fatty acids & Portugal & Serbia \\
\hline C6:0 & $0.02 \pm 0.00$ & $0.05 \pm 0.00$ \\
\hline $\mathrm{C} 8: 0$ & $0.02 \pm 0.01$ & $0.11 \pm 0.00$ \\
\hline C10:0 & $0.05 \pm 0.01$ & $0.04 \pm 0.00$ \\
\hline $\mathrm{C} 12: 0$ & $0.03 \pm 0.00$ & $0.03 \pm 0.00$ \\
\hline C13:0 & $0.01 \pm 0.00$ & nd \\
\hline $\mathrm{C} 14: 0$ & $0.20 \pm 0.01$ & $0.17 \pm 0.00$ \\
\hline $\mathrm{C} 14: 1$ & $0.02 \pm 0.00$ & $\operatorname{tr}$ \\
\hline $\mathrm{C} 15: 0$ & $0.80 \pm 0.01$ & $0.58 \pm 0.01$ \\
\hline $\mathrm{C} 16: 0$ & $9.64 \pm 0.04$ & $9.62 \pm 0.13$ \\
\hline C16:1 & $0.46 \pm 0.03$ & $0.49 \pm 0.01$ \\
\hline $\mathrm{C} 17: 0$ & $0.24 \pm 0.00$ & $0.19 \pm 0.00$ \\
\hline C18:0 & $3.19 \pm 0.01$ & $2.65 \pm 0.15$ \\
\hline C18: $\ln 9$ & $24.64 \pm 0.14$ & $20.08 \pm 0.16$ \\
\hline $\mathrm{C} 18: 2 \mathrm{n} 6$ & $57.14 \pm 0.19$ & $63.97 \pm 0.46$ \\
\hline $\mathrm{C} 18: 3 \mathrm{n} 3$ & $0.39 \pm 0.01$ & $0.20 \pm 0.00$ \\
\hline C20:0 & $0.28 \pm 0.02$ & $0.16 \pm 0.00$ \\
\hline C20:1 & $0.15 \pm 0.04$ & $0.13 \pm 0.00$ \\
\hline $\mathrm{C} 20: 2$ & $0.18 \pm 0.03$ & $0.15 \pm 0.00$ \\
\hline $\mathrm{C} 20: 3 \mathrm{n} 3+\mathrm{C} 21: 0$ & $0.16 \pm 0.01$ & $0.08 \pm 0.00$ \\
\hline $\mathrm{C} 20: 5 \mathrm{n} 3$ & $0.14 \pm 0.01$ & $0.01 \pm 0.00$ \\
\hline $\mathrm{C} 22: 0$ & $0.40 \pm 0.04$ & $0.29 \pm 0.00$ \\
\hline $\mathrm{C} 22: \ln 9$ & $0.44 \pm 0.03$ & $0.21 \pm 0.00$ \\
\hline $\mathrm{C} 23: 0$ & $0.09 \pm 0.01$ & $0.11 \pm 0.00$ \\
\hline $\mathrm{C} 24: 0$ & $0.47 \pm 0.09$ & $0.32 \pm 0.00$ \\
\hline $\mathrm{C} 24: 1$ & $0.84 \pm 0.09$ & $0.38 \pm 0.00$ \\
\hline Total SFA ( $\%$ of total FA) & $15.44 \pm 0.10^{\mathrm{a}}$ & $14.30 \pm 0.29^{b}$ \\
\hline Total MUFA ( $\%$ of total FA) & $26.55 \pm 0.05^{\mathrm{a}}$ & $21.30 \pm 0.17^{\mathrm{b}}$ \\
\hline Total PUFA ( $\%$ of total FA) & $58.01 \pm 0.15^{\mathrm{b}}$ & $64.40 \pm 0.46^{\mathrm{a}}$ \\
\hline$\alpha$-Tocopherol $(\mu \mathrm{g} / 100 \mathrm{~g} \mathrm{dw})$ & $17.86 \pm 1.07^{\mathrm{a}}$ & $6.81 \pm 0.40^{b}$ \\
\hline$\beta$-Tocopherol $(\mu \mathrm{g} / 100 \mathrm{~g} \mathrm{dw})$ & $175.29 \pm 4.02^{\mathrm{a}}$ & $179.68 \pm 0.90^{\mathrm{a}}$ \\
\hline$\gamma$-Tocopherol $(\mu \mathrm{g} / 100 \mathrm{~g} \mathrm{dw})$ & nd & $13.61 \pm 1.40$ \\
\hline$\delta$-Tocopherol $(\mu \mathrm{g} / 100 \mathrm{~g} \mathrm{dw})$ & $101.79 \pm 7.04^{\mathrm{a}}$ & $19.82 \pm 0.40^{b}$ \\
\hline Total tocopherols $(\mu \mathrm{g} / 100 \mathrm{~g} \mathrm{dw})$ & $294.94 \pm 9.99^{\mathrm{a}}$ & $219.92 \pm 1.31^{\mathrm{b}}$ \\
\hline
\end{tabular}

Different letters in each row indicate significant differences between the samples $(p<0.05)$. Caproic acid (C6:0); Caprylic acid (C8:0); Capric acid (C10:0); Lauric acid (C12:0); Tridecylic acid (C13:0); Myristic acid (C14:0); Myristoleic acid (C14:1); Pentadecanoic acid (C15:0); Palmitic acid (C16:0); Palmitoleic acid (C16:1); Heptadecanoic acid (C17:0); Stearic acid (C18:0); Oleic acid (C18:1n9); Linoleic acid (C18:2n6); $\alpha$-Linolenic acid (C18:3n3); Arachidic acid (C20:0); Eicosenoic acid (C20:1); cis-11,14-Eicosadienoic acid (C20:2); cis-11,14,17Eicosatrienoic acid and Heneicosanoic acid (C20:3n3+C21:0); cis-5,8,11,14,17Eicosapentaenoic acid (C20:5n3); Behenic acid (C22:0); Behenic acid (C22:1n9); Tricosanoic acid (C23:0); Lignoceric acid (C24:0); Nervonic acid (C24:1). SFA- saturated fatty acids; 
MUFA- monounsaturated fatty acids; PUFA- polyunsaturated fatty acids. dw- dry weight; ndnot detected; tr- traces. 
Table 4. Antioxidant properties of the methanolic extracts (mean $\pm \mathrm{SD})$.

\begin{tabular}{llrr}
\hline & \multicolumn{3}{c}{ Suillus granulatus $(\mathrm{L}$.$) Roussel methanolic extracts$} \\
\hline Activity & Assay & Portugal & Serbia \\
\hline \multirow{2}{*}{ Reducing Power } & Folin-Ciocalteu assay $(\mathrm{mg} \mathrm{GAE} / \mathrm{g}$ extract) & $40.78 \pm 0.88^{\mathrm{b}}$ & $44.36 \pm 0.31^{\mathrm{a}}$ \\
& Ferricyanide/Prussian blue assay $\left(\mathrm{EC}_{50} ; \mathrm{mg} / \mathrm{mL}\right)$ & $0.57 \pm 0.01^{\mathrm{a}}$ & $0.41 \pm 0.01^{\mathrm{b}}$ \\
Radical scavenging activity & DPPH radical-scavenging activity assay $\left(\mathrm{EC}_{50} ; \mathrm{mg} / \mathrm{mL}\right)$ & $0.98 \pm 0.02^{\mathrm{a}}$ & $0.89 \pm 0.02^{\mathrm{b}}$ \\
Lipid peroxidation & $\beta$-carotene/linoleate assay $\left(\mathrm{EC}_{50} ; \mathrm{mg} / \mathrm{mL}\right)$ & $0.45 \pm 0.08^{\mathrm{a}}$ & $0.48 \pm 0.06^{\mathrm{a}}$ \\
inhibition & TBARS assay $\left(\mathrm{EC}_{50} ; \mathrm{mg} / \mathrm{mL}\right)$ & $0.03 \pm 0.00^{\mathrm{a}}$ & $0.02 \pm 0.01^{\mathrm{b}}$ \\
\hline
\end{tabular}

Different letters in each row indicate significant differences between the extracts $(p<0.05)$. Concerning the Folin-Ciocalteu assay, higher values mean higher reducing power; for the other assays, the results are presented in $\mathrm{EC}_{50}$ values, what means that higher values correspond to lower reducing power or antioxidant potential. $\mathrm{EC}_{50}$ : Extract concentration corresponding to $50 \%$ of antioxidant activity or 0.5 of absorbance for the Ferricyanide/Prussian blue assay. 
Table 5. Antibacterial properties of the methanolic extracts $(\mathrm{mg} / \mathrm{mL}$; mean $\pm \mathrm{SD})$.

\begin{tabular}{|c|c|c|c|c|c|}
\hline & & \multicolumn{4}{|c|}{ Suillus granulatus (L.) Roussel methanolic extracts } \\
\hline & & Portugal & Serbia & Streptomycin & Ampicillin \\
\hline \multirow{2}{*}{ Staphylococcus aureus } & MIC & $0.15 \pm 0.007^{b}$ & $0.05 \pm 0.00^{\mathrm{c}}$ & $0.04 \pm 0.002^{\mathrm{d}}$ & $0.25 \pm 0.00^{\mathrm{a}}$ \\
\hline & $\mathrm{MBC}$ & $0.2 \pm 0.02^{\mathrm{b}}$ & $0.1 \pm 0.007^{\mathrm{c}}$ & $0.09 \pm 0.003^{\mathrm{c}}$ & $0.37 \pm 0.007^{\mathrm{a}}$ \\
\hline \multirow{2}{*}{ Bacillus cereus } & MIC & $0.1 \pm 0.02^{\mathrm{b}}$ & $0.04 \pm 0.001^{\mathrm{c}}$ & $0.09 \pm 0.000^{\mathrm{b}}$ & $0.25 \pm 0.02^{\mathrm{a}}$ \\
\hline & $\mathrm{MBC}$ & $0.2 \pm 0.03^{\mathrm{b}}$ & $0.05 \pm 0.00^{\mathrm{c}}$ & $0.17 \pm 0.007^{\mathrm{b}}$ & $0.37 \pm 0.02^{\mathrm{a}}$ \\
\hline \multirow{2}{*}{ Micrococcus flavus } & MIC & $0.2 \pm 0.02^{\mathrm{a}}$ & $0.1 \pm 0.02^{\mathrm{b}}$ & $0.17 \pm 0.007^{\mathrm{b}}$ & $0.25 \pm 0.02^{\mathrm{a}}$ \\
\hline & $\mathrm{MBC}$ & $0.4 \pm 0.07^{\mathrm{a}}$ & $0.2 \pm 0.02^{\mathrm{c}}$ & $0.34 \pm 0.003^{\mathrm{b}}$ & $0.37 \pm 0.01^{\mathrm{ba}}$ \\
\hline \multirow{2}{*}{ Listeria monocytogenes } & MIC & $0.2 \pm 0.00^{\mathrm{b}}$ & $0.05 \pm 0.03^{\mathrm{c}}$ & $0.17 \pm 0.01^{b}$ & $0.37 \pm 0.009^{\mathrm{a}}$ \\
\hline & $\mathrm{MBC}$ & $0.4 \pm 0.003^{\mathrm{b}}$ & $0.2 \pm 0.000^{\mathrm{d}}$ & $0.34 \pm 0.01^{\mathrm{c}}$ & $0.49 \pm 0.003^{\mathrm{a}}$ \\
\hline \multirow{2}{*}{ Pseudomonas aeruginosa } & MIC & $0.15 \pm 0.02^{b}$ & $0.05 \pm 0.007^{\mathrm{c}}$ & $0.17 \pm 0.007^{\mathrm{b}}$ & $0.74 \pm 0.006^{\mathrm{a}}$ \\
\hline & $\mathrm{MBC}$ & $0.2 \pm 0.00^{\mathrm{c}}$ & $0.1 \pm 0.02^{\mathrm{d}}$ & $0.34 \pm 0.003^{\mathrm{b}}$ & $1.24 \pm 0.02^{\mathrm{a}}$ \\
\hline \multirow{2}{*}{ Salmonella typhimurium } & MIC & $0.15 \pm 0.007^{\mathrm{c}}$ & $0.05 \pm 0.00^{\mathrm{d}}$ & $0.17 \pm 0.007^{\mathrm{b}}$ & $0.37 \pm 0.007^{\mathrm{a}}$ \\
\hline & $\mathrm{MBC}$ & $0.2 \pm 0.01^{\mathrm{c}}$ & $0.1 \pm 0.000^{\mathrm{d}}$ & $0.34 \pm 0.003^{\mathrm{b}}$ & $0.49 \pm 0.01^{\mathrm{a}}$ \\
\hline \multirow{2}{*}{ Escherichia coli } & MIC & $0.15 \pm 0.00^{\mathrm{cb}}$ & $0.15 \pm 0.02^{\mathrm{c}}$ & $0.17 \pm 0.01^{\mathrm{b}}$ & $0.25 \pm 0.00^{\mathrm{a}}$ \\
\hline & $\mathrm{MBC}$ & $0.2 \pm 0.01^{\mathrm{c}}$ & $0.2 \pm 0.00^{\mathrm{d}}$ & $0.34 \pm 0.003^{\mathrm{b}}$ & $0.49 \pm 0.01^{\mathrm{a}}$ \\
\hline \multirow{2}{*}{ Enterobacter cloacae } & MIC & $0.15 \pm 0.03^{\mathrm{c}}$ & $0.1 \pm 0.00^{\mathrm{d}}$ & $0.26 \pm 0.006^{\mathrm{b}}$ & $0.37 \pm 0.007^{\mathrm{a}}$ \\
\hline & $\mathrm{MBC}$ & $0.2 \pm 0.01^{\mathrm{c}}$ & $0.2 \pm 0.007^{\mathrm{c}}$ & $0.52 \pm 0.007^{\mathrm{b}}$ & $0.74 \pm 0.003^{\mathrm{a}}$ \\
\hline
\end{tabular}

Different letters in each row indicate significant differences between the extracts $(p<0.05)$. MIC- minimum inhibitory concentration; MBC- minimum bactericidal concentration. 
Table 6. Antifungal properties of the methanolic extracts $(\mathrm{mg} / \mathrm{mL}$; mean $\pm \mathrm{SD})$.

Suillus granulatus (L.) Roussel methanolic extracts

\begin{tabular}{|c|c|c|c|c|c|}
\hline & & Portugal & Serbia & Ketoconazole & Bifonazole \\
\hline \multirow{2}{*}{ Aspergillus fumigatus } & MIC & $0.45 \pm 0.02^{\mathrm{a}}$ & $0.05 \pm 0.00^{\mathrm{d}}$ & $0.2 \pm 0.01^{b}$ & $0.15 \pm 0.02^{\mathrm{c}}$ \\
\hline & MFC & $0.8 \pm 0.02^{\mathrm{a}}$ & $0.2 \pm 0.02^{\mathrm{c}}$ & $0.5 \pm 0.00^{\mathrm{b}}$ & $0.2 \pm 0.01^{\mathrm{c}}$ \\
\hline \multirow{2}{*}{ Aspergillus versicolor } & MIC & $0.1 \pm 0.01^{\mathrm{b}}$ & $0.025 \pm 0.0007^{\mathrm{c}}$ & $0.2 \pm 0.02^{\mathrm{a}}$ & $0.1 \pm 0.02^{\mathrm{b}}$ \\
\hline & MFC & $0.2 \pm 0.02^{\mathrm{b}}$ & $0.1 \pm 0.01^{\mathrm{c}}$ & $0.5 \pm 0.02^{\mathrm{a}}$ & $0.2 \pm 0.01^{\mathrm{b}}$ \\
\hline \multirow{2}{*}{ Aspergillus ochraceus } & MIC & $0.1 \pm 0.00^{\mathrm{b}}$ & $0.025 \pm 0.002^{\mathrm{c}}$ & $0.15 \pm 0.02^{\mathrm{a}}$ & $0.15 \pm 0.007^{\mathrm{a}}$ \\
\hline & MFC & $0.2 \pm 0.00^{\mathrm{a}}$ & $0.05 \pm 0.007^{\mathrm{b}}$ & $0.2 \pm 0.01^{\mathrm{a}}$ & $0.2 \pm 0.01^{\mathrm{a}}$ \\
\hline \multirow{2}{*}{ Aspergillus niger } & MIC & $0.05 \pm 0.003^{c}$ & $0.05 \pm 0.01^{\mathrm{c}}$ & $0.2 \pm 0.00^{\mathrm{a}}$ & $0.15 \pm 0.001^{\mathrm{b}}$ \\
\hline & MFC & $0.1 \pm 0.02^{\mathrm{c}}$ & $0.1 \pm 0.00^{\mathrm{c}}$ & $0.5 \pm 0.02^{\mathrm{a}}$ & $0.2 \pm 0.007^{\mathrm{b}}$ \\
\hline \multirow{2}{*}{ Trichoderma víride } & MIC & $0.075 \pm 0.008^{\mathrm{b}}$ & $0.01 \pm 0.00^{\mathrm{c}}$ & $1.0 \pm 0.07^{\mathrm{a}}$ & $0.15 \pm 0.02^{\mathrm{b}}$ \\
\hline & MFC & $0.1 \pm 0.01^{\mathrm{cb}}$ & $0.05 \pm 0.00^{\mathrm{c}}$ & $1.5 \pm 0.10^{\mathrm{a}}$ & $0.2 \pm 0.02^{\mathrm{b}}$ \\
\hline \multirow{2}{*}{ Penicillium funiculosum } & MIC & $0.05 \pm 0.007^{\mathrm{b}}$ & $0.05 \pm 0.01^{\mathrm{b}}$ & $0.2 \pm 0.02^{\mathrm{a}}$ & $0.2 \pm 0.00^{\mathrm{a}}$ \\
\hline & MFC & $0.1 \pm 0.02^{\mathrm{c}}$ & $0.1 \pm 0.00^{\mathrm{c}}$ & $0.5 \pm 0.02^{\mathrm{a}}$ & $0.25 \pm 0.02^{\mathrm{b}}$ \\
\hline \multirow{2}{*}{ Penicillium ochrochloron } & MIC & $0.075 \pm 0.008^{c}$ & $0.05 \pm 0.00^{\mathrm{c}}$ & $1.0 \pm 0.07^{\mathrm{a}}$ & $0.2 \pm 0.01^{\mathrm{b}}$ \\
\hline & MFC & $0.1 \pm 0.01^{\mathrm{c}}$ & $0.2 \pm 0.007^{\mathrm{cb}}$ & $1.5 \pm 0.07^{\mathrm{a}}$ & $0.25 \pm 0.01^{\mathrm{b}}$ \\
\hline \multirow{2}{*}{ Penicillium verrucosum var. cyclopium } & MIC & $0.1 \pm 0.01^{\mathrm{b}}$ & $0.1 \pm 0.02^{\mathrm{b}}$ & $1.5 \pm 0.07^{\mathrm{a}}$ & $0.2 \pm 0.00^{\mathrm{b}}$ \\
\hline & MFC & $0.4 \pm 0.03^{b}$ & $0.2 \pm 0.02^{b}$ & $2.0 \pm 0.10^{\mathrm{a}}$ & $0.3 \pm 0.02^{\mathrm{b}}$ \\
\hline
\end{tabular}

Different letters in each row indicate significant differences between the extracts $(\mathrm{p}<0.05)$. MIC- minimum inhibitory concentration; MFC- minimum fungicidal concentration. 